Quality: Jurnal Kesehatan

Volume 15, Nomor 2 Tahun 2021

pISSN: 1978-4325, eISSN : 2655-2434, DOI: 10.36082/qjk.v15i2.299

\title{
FAKTOR-FAKTOR YANG BERHUBUNGAN DENGAN KEPATUHAN PEDAGANG MENJALANI PROTOKOL KESEHATAN DI PASAR CIBINONG
}

\author{
Dessy $^{1}$, Ella Nurlaela Hadi ${ }^{2}$ \\ ${ }^{1}$ Departemen Promosi Kesehatan dan Ilmu Perilaku, Magister Kesehatan Masyarakat, Universitas \\ Indonesia, Depok, Indonesia
}

\begin{tabular}{ll}
\hline Info Artikel & Abstrak \\
\hline Genesis Naskah: & COVID-19 merupakan penyakit yang disebabkan SARS-COV2. Pada bulan Mei 2020, Kecamatan \\
Submission: 5-7-2021 & Cibinong terbanyak ke-4 kasus terkonfirmasi COVID-19 yakni 18 kasus dengan kematian 16,6\%. \\
Revised:6-11-2021 & Kecamatan Cibinong merupakan daerah pusat pemerintahan dengan interaksi sosial yang tinggi. \\
Accepted: $16-11-2021$ & Tempat yang strategis dengan fasilitas umum dengan pemenuhan kebutuhan primer salah satunya \\
& adalah pasar. Penelitian ini bertujuan mengetahui faktor-faktor yang berhubungan dengan kepatuhan \\
& pedagang menjalani protokol kesehatan untuk mencegah penyebaran COVID-19 di Pasar Cibinong. \\
Kata Kunci: & Penelitian ini dilakukan melalui pendekatan kuantitatif desain studi cross sectional, sampel dalam \\
COVID-19 & penelitian ini berjumlah 110 pedagang secara random sampling. Pengumpulan data dilakukan \\
Protokol Kesehatan & melalui pengisian kuesioner online, data di analisis menggunakan uji chi-squere. Variabel dependen \\
Kepatuhan Pedagang & kepatuhan pedagang, sedangkan variabel independennya yakni umur, jenis kelamin, pengetahuan, \\
& persepsi kerentanan, persepsi keseriusan, persepsi manfaat, persepsi hambatan, kemampuan diri dan \\
& isyarat dalam bertindak. Penelitian menunjukan bahwa pengetahuan, persepsi kerentanan, persepsi \\
& keseriusan, persepsi hambatan dan isyarat dalam bertindak merupakan variabel memiliki hubungan \\
& bermakna dengan kepatuhan pedagang dalam menjalani protokol kesehatan di pasar. Adapun \\
& variabel yang tidak berhubungan terdiri umur, jenis kelamin, persepsi manfaat dan kemampuan diri. \\
& Untuk mengoptimalkan kepatuhan pedagang akan COVID-19 disarankan meningkatkan \\
& pengetahuan akan COVID-19 dan protokol kesehatan di pasar dengan pemberdayaan pedagang \\
& melalui pembentukan kader pencegahan COVID-19 dan system keamanan keliling, penyebaran \\
& informasi terkait dapat melalui group online paguyuban pedagang pasar, SMS LBA serta pemenuhan \\
& fasilitas cuci tangan.
\end{tabular}

\section{FACTORS RELATING TO TRADERS COMPLIANCE ON PRACTICING HEALTH PROTOKOL IN CIBINONG MARKET}

\begin{tabular}{ll}
\hline Keywords: & Abstract \\
\cline { 2 - 2 } COVID-19 & COVID-19 is a disease caused by SARS-CoV2. In May 2020, Cibinong District was the 4th most \\
Health protokols & confirmed case of COVID-19. It was reported 18 cases with 16.6\% mortality. Cibinong is central \\
Compliance of traders & government area with high social interaction. One of place with public facilities to fulfill primary \\
& needs is the market. The purpose of this study was to determine the factors related to merchant \\
& compliance with health protocols to prevent the spread of COVID-19 at Cibinong Market. This si \\
& crossectional research, the sample in this study is 110 traders taken using random sampling. Data \\
& was collected through filling out an online questionnaire, the data was analyzed using the chi-square \\
& test. Dependent variables traders compliance, independent variabel that is age, gender, knowledge, \\
& perceived vulnerability, perceived seriousness, perceived barriers, perceived benefits, self-ability \\
& and cues in action. The results showed that knowledge, perceived vulnerability, perceived \\
& seriousness, perceived barriers and cues in action were variables that had a significant relationship \\
& with traders' compliance with health protocols in the market. The unrelated variables consist of age, \\
& gender, perceived benefits and self-ability. To optimize trader compliance with COVID-19, it is \\
\hline
\end{tabular}

(C) Poltekkes Kemenkes Jakarta I

Jl. Wijaya Kusuma No. 47-48 Cilandak Jakarta Selatan, Indonesia

email: jurnalquality@poltekkesjakarta1.ac.id 
recommended to increase knowledge of COVID-19 and health protocols in the market by empowering traders through the formation of COVID-19 prevention cadres and mobile security systems, dissemination of related information can be through the online group of market traders, SMS LBA as well as the fulfillment of hand washing facilities.

\author{
Korespondensi Penulis: \\ Dessy \\ Departemen Promosi Kesehatan dan Ilmu Perilaku \\ Email: dessydamanhuri30@gmail.com
}




\section{Pendahuluan}

COVID-19 merupakan penyakit yang disebabkan SARS-COV2. Penyakit ini ditularkan melalui manusia ke manusia dengan 2 cara melalui penularan langsung (menghirup air liur yang mengandung SAR-COV2) dan tidak langsung (menyentuh benda atau zat yang sudah terkontaminasi SARS-COV2). Penyakit ini pertama kali ditemukan di daerah Wuhan, Cina pada bulan Januari 2020 dan tanggal 11 Januari 2020 menyebar sampai dengan ke 24 negara (Olapegba P.O, 2020)

Pada bulan Mei 2020 WHO mengemukakan, terdapat 216 negara terpapar COVID-19 dengan jumlah kasus terkonfirmasi 5.934.136 kasus dengan 367.166 kematian $(21,8 \%)$. Adapun negara tertinggi kasus terkonfirmasi adalah Amerika Serikat mencapai 243.793 kasus dengan 157.702 kematian $(5,74 \%)$. India merupakan negara tertinggi di Asia penderita COVID-19 kasus terkonfirmasi yaitu sebanyak182.143 kasus dengan 5.164 kematian (28,35\%) (Romanov, 2020). Pada bulan Mei 2020, Indonesia kasus COVID-19 mengalami kenaikan signifikan kasus terkonfirmasi mencapai 27.473 kasus dengan kematian 1.613 jiwa (6.09\%). Dari 34 Provinsi yang ada di Indonesia, Provinsi Jawa Barat merupakan peringkat ke-4 penderita COVID-19 dengan kasus terkonfirmasi sebanyak 2.376 jiwa dan kematian sebanyak 158 jiwa (6,64\%). Di Provinsi Jawa Barat bulan Mei 2020, Kabupaten Bogor menjadi peringkat ke-4 penderita COVID-19 dengan kasus terkonfirmasi 203 jiwa dan kematian 15 jiwa $(7,38 \%)^{8}$. Pada bulan Mei 2020, Kecamatan Cibinong peringkat ke 4 se-Kabupaten Bogor penderita COVID-19 dengan kasus terkonfirmasi sebanyak 18 jiwa dan kematian 3 jiwa $(16,6 \%)$ (Satgas COVID19, 2020a).

Kecamatan Cibinong merupakan wilayah administrasi pusat pemerintahan dari Kabupaten Bogor dan wilayah yang memiliki penduduk terpadat ke-2. Selain itu, kecamatan ini merupakan pusat perekonomian yang ditunjang dengan akses transfortasi dan fasilitas. Untuk mendapatkan berbagai kebutuhan primer yang mudah diakses, salah satu fasilitas umum di Kecamatan ini adalah Pasar Cibinong merupakan pasar tradisional yang dikelola oleh Pemerintah Daerah (BPS Kabupaten Bogor, 2018) Pasar merupakan tempat berkerumunya orang dalam melakukan kegiatan primer untuk memenuhi kebutuhan pokok yang

(C) Poltekkes Kemenkes Jakarta I

J1. Wijaya Kusuma No. 47-48 Cilandak Jakarta Selatan, Indonesia email: jurnalquality@poltekkesjakarta1.ac.id dapat berpotensi menjadi tempat penularan COVID19. Kepadatan penduduk dan interaksi sosial yang tinggi, menjadikan pasar salah satu tempat yang berpotensi sebagai tempat penularan COVID-19 (Mulyati et al., 2016)

Untuk mencegah penularan COVID-19, WHO mengupayakan berbagai langkah strategis yang meliputi mobilisasi di berbagai sector dan komunitas, mengontrol kasus sporadic dan cluster, memekan penyebaran di tingkat komunitas dan mengurangi angka kematian yang diakibatkan SARS-COV2. Strategi dalam mencegah penyebaran COVID-19 yaitu dengan memakai masker, melakukan cuci tangan memakai sabun di bawah air mengalir, menjaga jarak dan mengurangi mobilitas kelompok (WHO, 2020).

Pemerintah Indonesia melakukan anjuran dari WHO untuk pencegahan penyebaran COVID-19. Selain itu berbagai pencegahan diantaranya dengan jaga jarak antar individu dan social distancing di area publik, karantina Kesehatan, pembatasan sosial berskala besar (PSBB). Penutupan fasilitas publikpun dilakukan terkecuali penyedia kebutuhan pokok dan fasilitas pelayanan Kesehatan dengan menerapkan protokol Kesehatan (WHO, 2020). Kabupaten Bogor menerapkan protokol kesehatan tempat umum sesuai dengan anjuran pemerintah sampai dengan ke tingkat masyarakat terbawah. Upaya pencegahan penyebaran COVID-19 dilakukan sampai dengan pengawasan tingkat rukun tetangga (RT) yaitu dengan pengawasan gerbang masuk dengan membuat portal dan melakukan desinfeksi pada warga atau orang yang melaluinya, pengukuran suhu tubuh kepada setiap warga yang masuk wilayah. Upaya pencegahanpun dilakukan di tempat umum salah satunya pasar. Protokol kesehatan di tempat umum salah satunya area pasar yang tercantum dalam Peraturan Bupati Bogor Nomor 40/2020. Adapun peraturan tersebut sebagai berikut yakni: jam operasional dari pasar jam 04.0013.00 WIB, tidak menyediakan kursi didalam maupun diluar kios/lapak, menyediakan fasilitas mencuci tangan dengan sabun atau menggunakan handsanitizer, memakai masker. Selain itu protokol Kesehatan lainnya menjaga jarak antar lapak, pembeli dan pedagang lainnya minimal 1 meter, menggunakan face shield/ pembatas transparan yang di pasang di depan lapak/toko dan membersihkan

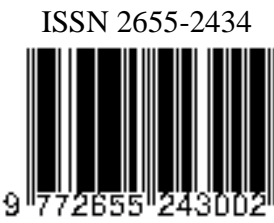


kios/lapak sebelum dan setelah berjualan (Satgas COVID19, 2020b).

Berbagai upaya pencegahan penyebaran SARSCOV2 telah dilakukan oleh pemerintah, namun kasus terkonfirmasi dan kematian COVID-19 semakin meningkat. Hal ini kemungkinan disebabkan kurangnya kesadaran dari masyarakat akan pentingnya protokol kesehatan. Melansir dari media online, masih adanya masyarakat yang tidak mengindahkan himbauan protokol kesehatan di Pasar. Di Pasar Ciluer Kecamatan Sukaraja, pasar dipadati oleh warga menjelang lebaran pada saat PSBB dengan mengabaikan masker, mencuci tangan dan jaga jarak.(tribunnews.com, 2020) Tanggal 16 Juni 2020 munculnya klaster baru di Pasar Cileungsi yang didominasi oleh pedagang.(Kompas.com, 2020) COVID-19 Klaster baru kembali merebak di Pasar Raya Padang tanggal 8 Juli 2020, dinyatakan 248 orang terpapar SARS-COV2 dikarenakan banyak yang tidak mematuhi protokol kesehatan.(frame.grid.id, 2020)

Perilaku ketaatan dan kepatuhan dipengaruhi oleh keyakinan dan kepercayaan individu dapat menentukan upaya Kesehatan tersebut. Teori HBM (Health Belief Model) mengatakan terdapat 4 persepsi yang mempengaruhi perilaku yakni persepsi kerentanan (perceived susceptibility), persepsi keseriusan (perceived seriousness), persepsi manfaat (perceived benefits), persepsi hambatan (perceived barriers), isyarat akan bertindak (cues to action) dan kepercayaan diri (self-efficacy) yang dipengaruhi oleh faktor modifikasi terdiri dari berbagai unsur seperti demografi, sosiopsikologis dan structural (McKenzie et al., 2013)

Penelitian kepatuhan masyarakat khususnya pada pedagang dalam pencegahan COVID-19 di pasar masih sangat minim dilakukan sehingga peneliti mencantumkan referensi penelitian kepatuhan sebelumnya. Penelitian Nurlaila menyatakan terdapat hubungan yang bermakna antara pengetahuan filariasis, persepsi kerentanan, persepsi keparahan, persepsi manfaat, isyarat akan bertindak dengan kepatuhan minum obat filariasis (Nurlaila 2017). Penelitian lain, Chairunisa menunjukan adanya hubungan yang bermakna antara persepsi ancaman, persepsi manfaat, persepsi hambatan dengan kepatuhan minum obat. (Chairunisa et al., 2019) Paparan sebelumnya, didapatkan tujuan dari penelitian ini yakni faktor-faktor yang berhubungan

(C) Poltekkes Kemenkes Jakarta I

J1. Wijaya Kusuma No. 47-48 Cilandak Jakarta Selatan, Indonesia email: jurnalquality@ poltekkesjakarta1.ac.id dengan kepatuhan pedagang menjalani protokol kesehatan untuk mencegah penyebaran COVID-19 di Pasar Cibinong Kecamatan Cibinong Kabupaten Bogor.

\section{Metode}

Penelitian ini merupakan penelitian kuantitatif dengan desain cross sectional study, lokasinya di Pasar Cibinong Kecamatan Cibinong Kabupaten Bogor pada bulan Desember 2020. Populasi dalam penelitian ini sebanyak 368 orang pedagang yang terdaftar pada paguyuban di Pasar Cibinong, sedangkan sampel penelitian ini sebanyak 110 orang yang terpilih secara acak sederhana dengan cara mengundi anggota paguyuban.

Sampel ditentukan menggunakan rumus Lamenshow uji beda dua proporsi yang dapat dilihat sebagai berikut (Lemeshow et al., 1997):

$\begin{array}{ll}\text { Keterangan : } & \\ & \text { Besar Sampel } \\ Z_{1-\alpha / 2} & \text { Derajat kepercayaan 5\% }(1,96) \\ Z_{1-\beta} & \text { Kekuatan uji } 80 \%(0,84) \\ \mathrm{P}_{1} & \text { Respon responden dengan kriteria } \\ & \text { positif dan patuh menjalani protokol } \\ & \text { kesehatan } \\ & =\text { Respon responden dengan kriteria } \\ & \text { negatif dan patuh menjalani } \\ \mathrm{P}_{2} & \text { protokol kesehatan } \\ & =(\mathrm{P} 1+\mathrm{P} 2) / 2 \\ \mathrm{p} & =0,05 \\ \alpha & =0,80 \\ 1-\beta & \end{array}$

Adapun pengambilan data dilakukan dengan menggunakan kuesioner yang terkait dengan protokol Kesehatan di pasar yang tercantum dalam Surat Edaran Bupati Bogor No.60/2020 tentang Pembatasan Sosial Berskala Besar (PSBB) Pra Adapatasi Kebiasaan Baru (Satgas COVID19 Kabupaten Bogor, 2020). Kuesioner inipun telah di uji validitas dan reliabilitas terhadap 25 orang, didapat nilai $r$ hitung $(0,707-0,910)$ lebih besar dibandingkan $r$ tabel $(0,336)$ sehingga pertanyaan dalam kuesioner dinyatakan valid. Adapun uji reliabilitas

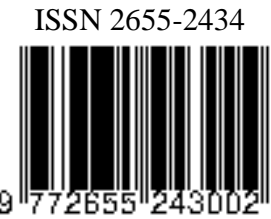


menggunakan tehnik crobach's alpha dan instrumen penelitian ini reliable $(0,981)$.

Variabel dependen dalam penelitian ini adalah kepatuhan pedagang menjalani protokol Kesehatan. Variabel independen terdiri umur, jenis kelamin, pengetahuan, persepsi kerentanan, persepsi keseriusan, persepsi hambatan, persepsi manfaat, kemampuan diri dan isyarat dalam bertindak. Pengumpulan data dilakukan secara online dengan menggunakan google form yang disebar ke pedagang sesuai dengan sampel melalui pesan singkat online. Dalam penelitian ini, data dianalisis secara univariat dan bivariat dengan menggunakan uji person chi-squere dan fisher's exact test (nilai harapan $<5 \%$ ). Selanjutnya, penelitian ini telah melalui kaji etik Universitas Indonesia Fakultas Kesehatan Masyarakat dengan nomor: Ket715/UN2.F10.D11/PPM.00.02/2020.

\section{Hasil dan Pembahasan}

\section{Hasil}

Pedagang yang patuh akan protokol kesehatan sebanyak 8,20\%. Usia 18-45 tahun terbanyak yaitu $85,5 \%$ dan rerata berumur 32,52 tahun dengan jenis kelamin laki-laki yaitu $76,4 \%$. Pedagang yang berpengetahuan baik sebanyak 20\% dapat dilihat pada Tabel 1.

Tabel 1. Distribusi Pedagang Menurut Faktor Modifikasi Dalam Menjalani Protokol Kesehatan di Pasar Cibinong Kecamatan Cibinong Kabupaten Bogor 2020

\begin{tabular}{|c|c|c|}
\hline \multirow{2}{*}{ Variabel } & Frekuensi & Persentase \\
\hline & $\mathbf{N}$ & $\%$ \\
\hline \multicolumn{3}{|c|}{ Kepatuhan Pedagang } \\
\hline Patuh & 9 & 8,2 \\
\hline Kurang Patuh & 101 & 91,8 \\
\hline \multicolumn{3}{|l|}{ Usia } \\
\hline $18-45$ tahun & 94 & 85,5 \\
\hline $46-65$ tahun & 16 & 14,5 \\
\hline \multicolumn{3}{|l|}{ Jenis Kelamin } \\
\hline Laki-laki & 84 & 76,4 \\
\hline Perempuan & 26 & 23,6 \\
\hline \multicolumn{3}{|l|}{ Pengetahuan } \\
\hline Baik & 22 & 20 \\
\hline Kurang & 88 & 80 \\
\hline \multicolumn{3}{|c|}{ Persepsi Kerentanan } \\
\hline Rentan & 27 & 24,5 \\
\hline Tidak Rentan & 83 & 75,5 \\
\hline
\end{tabular}

Tabel 2 memperlihatkan, pedagang yang merasa dirinya rentan terkena COVID-19 sebesar $24,5 \%$ sedangkan yang merasa serius dalam memandang COVID-19 merupakan penyakit yang serius sebesar 66,4\%. Adapun pedagang yang menyatakan bahwa memakai protokol kesehatan di pasar bermanfaat mencegah penularan COVID-19 sebanyak $32,7 \%$ dan yang menyatakan tidak adanya hambatan dalam menggunakan protokol kesehatan di pasar sebanyak 25,5\%. Pedagang yang mengatakan jika dirinya mendapat isyarat akan bertindak dalam hal ini dukungan dalam melakukan pencegah COVID_-19 melalui protokol kesehatan sebesar $29,1 \%$, sedangkan yang mengatakan bahwa dirinya memiliki kemampuan diri dalam melakukan tindakan pencegahan dengan menggunakan protokol kesehatan sebesar 32,7\%.

Tabel 2. Distribusi Pedagang Menurut Persepsi, Isyarat Akan Bertindak dan Kemampuan Diri

Dalam Menjalani Protokol Kesehatan di Pasar Cibinong Kecamatan Cibinong Kabupaten Bogor 2020

\begin{tabular}{lcc}
\hline \multirow{2}{*}{ Variabel } & Frekuensi & Persentase \\
\cline { 2 - 3 } & $\mathbf{N}$ & $\mathbf{\%}$ \\
\hline Persepsi Keseriusan & & \\
\hline Serius & 73 & 66,4 \\
\hline Tidak Serius & 37 & 33,6 \\
\hline Persepsi Manfaat & & \\
\hline Bermanfaat & 36 & 32,7 \\
\hline Tidak Bermanfaat & 74 & 67,3 \\
\hline Persepsi Hambatan & & \\
\hline Tidak Ada & 28 & 25,5 \\
\hline Ada & 82 & 74,5 \\
\hline Isyarat Akan Bertindak & & 29,1 \\
\hline Ada & 32 & 70,9 \\
\hline Tidak & 78 & 32,7 \\
\hline Kemampuan Diri & & 67,3 \\
\hline Ada & 36 & \\
\hline Tidak & 74 & \\
\hline
\end{tabular}

Hasil dari analisa bivariat dapat di lihat pada Tabel 3 menunjukan, proporsi pedagang berumur 18-45 tahun lebih patuh protokol kesehatan dibandingkan dengan umur 46-65 tahun dengan pvalue $=1,00 \quad(\mathrm{OR}=1,395, \mathrm{CI}: 0,2-12,0)$. Dapat disimpulkan, tidak adanya hubungan yang bermakna antara umur dengan kepatuhan pedagang dalam menjalani protokol kesehatan. Hasil uji

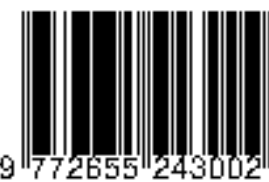




\begin{tabular}{|c|c|c|c|}
\hline \multirow[t]{3}{*}{ Variabel } & \multicolumn{2}{|c|}{ Kepatuhan } & \multirow{3}{*}{$\begin{array}{c}\text { OR } \\
(95 \% \mathrm{CI})\end{array}$} \\
\hline & Patuh & $\begin{array}{c}\text { Kurang } \\
\text { Patuh }\end{array}$ & \\
\hline & n $\%$ & n $\%$ & \\
\hline
\end{tabular}

\section{Umur}

\begin{tabular}{|c|c|c|c|c|c|c|}
\hline $18-45$ tahun & 8 & 8,5 & 86 & 91,5 & 1,0 & 1,395 \\
\hline $45-65$ tahun & 1 & 6,3 & 15 & 93,8 & 00 & $\begin{array}{l}(0,2- \\
12,0)\end{array}$ \\
\hline
\end{tabular}

\section{Jenis Kelamin}

\begin{tabular}{|c|c|c|c|c|c|c|}
\hline Laki-Laki & 6 & 7,1 & 78 & 92,9 & 0,4 & 0,590 \\
\hline Perempuan & 3 & 11,5 & 23 & 88,5 & 39 & $(0,1-2,5)$ \\
\hline \multicolumn{7}{|l|}{ Pengetahuan } \\
\hline Baik & 8 & 36,4 & 14 & 63,6 & 0,0 & 49,714 \\
\hline Kurang & 1 & 1,1 & 87 & 98,9 & 01 & $\begin{array}{c}(5,7- \\
428,5)\end{array}$ \\
\hline \multicolumn{7}{|c|}{ Persepsi Kerentanan } \\
\hline Rentan & 7 & 25,9 & 20 & 74,1 & 0,0 & 14,175 \\
\hline $\begin{array}{l}\text { Tidak } \\
\text { Rentan }\end{array}$ & 2 & 2,4 & 81 & 97,6 & 01 & $\begin{array}{l}(2,7- \\
73,5)\end{array}$ \\
\hline \multicolumn{7}{|c|}{ Persepsi Keseriusan } \\
\hline Serius & 9 & 12,3 & 64 & 87,7 & 0,0 & 0,877 \\
\hline Tidak Serius & 0 & 0 & 37 & 100 & 27 & $(0,8-0,9)$ \\
\hline
\end{tabular}

\begin{tabular}{|c|c|c|c|c|c|c|}
\hline Bermanfaat & 3 & 8,3 & 33 & 91.7 & 1,0 & 1,030 \\
\hline $\begin{array}{l}\text { Tidak } \\
\text { Bermanfaat }\end{array}$ & 6 & 8,1 & 68 & 91.9 & 00 & $\begin{array}{l}(0,24- \\
4,37)\end{array}$ \\
\hline \multicolumn{7}{|c|}{ Persepsi Hambatan } \\
\hline Ada & 5 & 17,9 & 23 & 82,1 & 0,0 & 4,239 \\
\hline Tidak Ada & 4 & 4,9 & 78 & 95,1 & 45 & $\begin{array}{l}(1,0- \\
17,1)\end{array}$ \\
\hline \multicolumn{7}{|c|}{ Isyarat Dalam Bertindak } \\
\hline Ada & 6 & 18,8 & 26 & 81,3 & 0,0 & 5,769 \\
\hline Tidak Ada & 3 & 3,8 & 75 & 96,2 & 17 & $\begin{array}{l}(1,3- \\
24,7)\end{array}$ \\
\hline \multicolumn{7}{|c|}{ Kemampuan Diri } \\
\hline Ada & 5 & 13,9 & 31 & 86,1 & 0,1 & 2,823 \\
\hline Tidak Ada & 4 & 5,4 & 70 & 94,6 & 50 & $\begin{array}{l}(0,70- \\
11,23)\end{array}$ \\
\hline
\end{tabular}

analisa didapatkan, proporsi pedagang perempuan yang patuh menjalani protokol kesehatan lebih besar yakni $11,5 \%$ dibandingkan pedagang lakilaki dengan nilai p-value $=0,439$. Hal ini menandakan tidak ada hubungan yang bermakna antara jenis kelamin dengan kepatuhan pedagang dalam menjalani protokol kesehatan.

Proporsi pedagang yang berpengetahuan baik lebih banyak $(36,4 \%)$ dibandingan dengan pedagang yang berpengetahuan kurang yang patuh. Hasil uji statistik menunjukan $\mathrm{P}$-value $=0,001$

(C) Poltekkes Kemenkes Jakarta I

Jl. Wijaya Kusuma No. 47-48 Cilandak Jakarta Selatan, Indonesia email: jurnalquality@poltekkesjakarta1.ac.id
$(\mathrm{OR}=49,714,95 \%$ CI: 5,7-428,5), yang berarti terdapat hubungan

yang bermakna antara pengetahuan dengan kepatuhan pedagang dalam menjalani protokol kesehatan dan pedagang yang berpengetahuan baik lebih berpeluang 50 kali lebih patuh menjalani protokol kesehatan dibandingkan dengan yang berpengetahuan kurang.

Tabel 3. Hubungan Antara Faktor Modifikasi, Persepsi, Isyarat Dalam Bertindak Dan

Kemampuan Diri Menjalani Protokol Kesehatan di Pasar Cibinong Kecamatan Cibinong Kabupaten Bogor 2020

Dari hasil analisa didapatkan, proporsi pedagang yang memiliki keyakinan dirinya rentan tekena COVID-19 yang patuh menjalankan protokol kesehatan lebih banyak $(25,9 \%)$ dibandingkan pedagang yang berkeyakinan tidak rentan namun patuh menjalankan protokol kesehatan dengan nilai p-value $=0,001$ $(\mathrm{OR}=14,175,95 \%$ CI: 2,7-73,5). Hal tersebut menunjukan, adanya hubungan yang signifikan antara pedagang yang berkeyakinan rentan tertular COVID-19. dengan kepatuhan pedagang. Pedagang yang memiliki keyakinan rentan tertular COVID-19 berpeluang 14 kali lebih patuh menjalani protokol kesehatan dibandingkan dengan pedagang yang tidak berkeyakinan rentan akan COVID-19.

Dapat dilihat juga, sebanyak $12,3 \%$ proporsi pedagang memiliki keyakinan COVID-19 merupakan penyakit serius lebih banyak yang patuh menjalani protokol kesehatan dibandingkan yang tidak berkeyakinan COVID-19 penyakit serius tetapi patuh menjalani protokol kesehatan. Hasil uji statistik memperlihatkan p-value $=0,027$ (OR=0,877, 95\% CI: 0,8-0,9), memiliki arti adanya hubungan pedagang berkeyakinan bahwa COVID19 penyakit serius yang patuh menjalani protokol kesehatan dengan pedagang yang tidak berkeyakinan COVID-19. Pedagang yang memiliki keyakinan COVID-19 merupakan penyakit yang serius 0,8 kali lebih patuh dibandingkan pedagang yang berkeyakinan COVID-19 bukan penyakit yang serius.

Selanjutnya Tabel 3, menjelaskan sebanyak 8,3\% proporsi pedagang yang mempersepsikan terdapat manfaat patuh menjalani protokol kesehatan

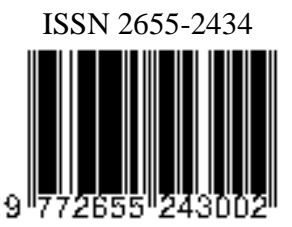


dibandingkan dengan pedagang yang mempersepsikan tidak bermanfaat. Didapatkan pvalue $=1,000 \quad(\mathrm{OR}=1,030, \quad 95 \% \quad \mathrm{CI}: \quad 0,24-4,37)$ menunjukan tidak terdapat hubungan yang berhubungan antara pedagang memiliki persepsi manfaat dengan kepatuhan pedagang menjalani protokol kesehatan.

Proporsi pedagang yang tidak memiliki hambatan dan patuh dalam menjalani protokol Kesehatan sebesar $17,1 \%$. Uji statistik memperlihatkan, terdapat hubungan yang signifikan antara pedagang yang tidak memiliki hambatan dan patuh dengan pedagang yang memiliki hambatan menjalani protokol kesehatan dengan $\mathrm{p}$-value $=0,04$ $(\mathrm{OR}=4,239,95 \% \mathrm{CI}: 1,0-17,1)$. Selanjutnya dapat diartikan pedagang yang tidak ada hambatan Kesehatan berpeluang sekitar 4 kali untuk lebih patuh menjalani protokol Kesehatan dibandingkan pedagang yang memiliki hambatan.

Hasil analisis menunjukan, proporsi pedagang yang memiliki isyarat dalam bertindak patuh menjalankan protokol kesehatan lebih besar $(18,8 \%)$ dibandingkan pedagang tidak memiliki isyarat dalam bertindak menjalani protokol kesehatan dengan $\mathrm{p}$ value $=0,017(\mathrm{OR}=5,769,95 \% \mathrm{CI}: 1,3-24,7)$. Dari hasil tersebut didapatkan, adanya hubungan yang bermakna antara isyarat dalam bertindak dengan kepatuhan pedagang menjalani protokol Kesehatan dan pedagang yang memiliki isyarat dalam bertindak berpeluang hampir 6 kali untuk patuh menjalankan protokol Kesehatan.

Proporsi pedagang yang berkeyakinan mampu patuh menjalani protokol kesehatan sebanyak 13,9\% dibandingkan yang tidak mampu menjalankan protokol kesehatan. Uji statistik menunjukan pvalue $=0,150(\mathrm{OR}=2,823,95 \% \mathrm{CI}: 0,70-11,23)$, tidak ada hubungan yang bermakna antara pedagang yang memiliki kemampuan diri dengan kepatuhan pedagang dalam menjalani protokol Kesehatan.

\section{Pembahasan}

Kepatuhan merupakan respon seseorang terhadap suatu perintah, peraturan atau ajakan yang direalisasikan melalui suatu tindakan nyata. Protokol Kesehatan pada pedagang di pasar ditetapkan dan dianjurkan sebagai upaya untuk pencegahan penyebaran COVID-19 yang tercantum dalam Peraturan Bupati Bogor yakni memakai masker, mencuci tangan memakai sabun atau handsanitizer,

(C) Poltekkes Kemenkes Jakarta I

Jl. Wijaya Kusuma No. 47-48 Cilandak Jakarta Selatan, Indonesia email: jurnalquality@poltekkesjakarta1.ac.id menjaga jarak minimal 1 meter, memasang pembatas transparan atau menggunakan face shield dan membersihkan kios/lapak sebeum dan sesudah berjualan (Bogor, 2020)

Hasil penelitian menunjukan, hanya sebagian kecil pedagang yang mematuhi protokol kesehatan $(8,2 \%)$. Hal ini sesuai dengan penelitian Siahaineinia, mengemukankan kurang dari setengah pedagang $(46,4 \%)$ yang patuh melaksanakan protokol Kesehatan di Pasar Pagi Kota Medan (Siahaineinia et al., 2020). Begitu pula dengan Shahnanzi yang menyatakan sebanyak 22\% masyarakat patuh menggunakan protokol kesehatan sebagai bentuk pencegahan COVID-19 Satgas Covid-19 pemantauan kedisiplinan protokol kesehatan yang dilakukan bulan November 2020 menyatakan, dari 512 kabupaten/kota yang ada di Indonesia hanya sebagian kecil yang patuh memakai masker (9\%) dan menjaga jarak (4\%) (Shahnazi, 2020) Milgram (1973) dalam penelitian kepatuhan mengemukakan, kepatuhan seseorang dipengaruhi oleh pengawasan dan hukuman, dalam hal ini menunjukan bahwa seseorang yang mempunyai jabatan memiliki kekuasaan. Selain itu, kepatuhan juga merupakan perilaku yang dipengaruhi oleh tekanan sosial dan dapat diukur melalui keyakinan, penerimaan sehingga menghasilkan Tindakan (Wade et al., 2016)

Pemerintah berupaya mencegah dan memutus mata rantai COVID-19 telah dilakukan melalui himbauan, anjuran, menerbitkan peraturan sampai dengan memberikan memberikan sanksi namun pelanggar aturan protokol Kesehatan masih tetap ada. Hasil analisis peneliti mengemukakan, hal tersebut kemungkinan salah satunya disebabkan kesadaran yang bukan dari individu tetapi disebabkan adanya ketakukan pada petugas dan hukuman pelanggaran protokol kesehatan. Selain itu, kurangnya kesadaran dari dalam diri memahami pentingnya mematuhi protokol Kesehatan menjadikan sedikitnya individu yang patuh aturan tersebut. Untuk mengatasinya diperlukan pendekatan melalui kelompok sosial/paguyuban yang berpengaruh disertai pengawasan. Untuk pengawasan mematuhi protokol Kesehatan, hendaknya dibentuk Sispenling CO.

Kepatuhan individu dipengaruhi oleh beberapa hal, menurut Health Belief Model (HBM) Theory terdapat beberapa keyakinan seseorang

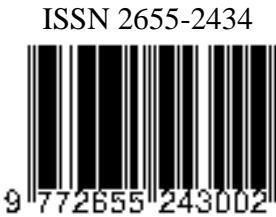


menyertainya yakni persepsi kerentanan, persepsi keseriusan, persepsi manfaat, persepsi hambatan, isyarat dalam bertindak dan kemampuan diri, Keyakinan tersebut dipengaruhi oleh beberapa faktor antara lain: modifikasi (usia, jenis kelamin), sosiopsikologis, struktural (pengetahuan) (McKenzie et al., 2013).

Hasil penelitian menunjukan dari 9 variabel yang diduga sebagai faktor yang berhubungan, 5 variabel yang signifikan memiliki hubungan dengan kepatuhan pedagang yaitu pengetahuan, persepsi kerentanan, persepsi keseriusan, persepsi hambatan dan isyarat dalam bertindak. Adapun 4 variabel lainnya yang tidak memiliki hubungan tersebut adalah usia, jenis kelamin, persepsi manfaat dan kemampuan diri.

Rosenstock dalam Teori HBM mengatakan, pengetahuan merupakan faktor yang berpengaruh langsung kepada persepsi kerentanan. Teori Taksinomi Bloom berpendapat, pengetahuan menggambarkan proses berpikir yang lebih tinggi yang dapat dilihat dalam proses penerapannya sehingga dapat digunakan untuk menyelesaikan suatu masalah (McKenzie et al., 2013). Hasil penelitian memperlihatkan, terdapat hubungan yang bermakna antara pengetahuan tentang COVID-19 dan protokol kesehatan dengan kepatuhan pedagang menjalani protokol kesehatan. Menurut Notoatmodjo, pengetahuan yang dimiliki individu merupakan salah satu strategi untuk pembentuk serta perubahan perilaku seseorang yang dibutuhkan dengan pemberian informasi (Notoatmodjo, 2014). Sejalan dengan penelitian Nismawati dalam yang dilakukan terdapat hubungan pengetahuan pada pelaku usaha mikro dengan kepatuhan akan penerapan protokol Kesehatan (Nismawati \& Marhtyni, 2020). Begitupun Winarti menuliskan adanya hubungan pengetahuan dengan kepatuhan masyarakat dalam pembatasan sosial berskala besar yang dilakukan di Kota Depok (Wiranti et al., 2020). Pengetahuan yang baik akan menambah pemahaman pedagang tentang pentingnya mematuhi protokol Kesehatan. Selain itu, peningkatan pengetahuan pedagang mengenai protokol Kesehatan dapat meningkatkan kedisiplinan dan mempengaruhi keyakinan pedagang dalam melakukan tindakan kesehatan untuk mencegah penularan COVID-19 di pasar. Pengetahuan pedagang dapat diperoleh dengan meningkatkannya dapat melalui berbagai hal

(C) Poltekkes Kemenkes Jakarta I

Jl. Wijaya Kusuma No. 47-48 Cilandak Jakarta Selatan, Indonesia email: jurnalquality@poltekkesjakarta1.ac.id yakni meningkatkan informasi dengan media yang ada seperti speaker sentral, spanduk, SMS LBA dan melalui pemberdayaan pedagang dengan pembentukan kader pencegahan COVID-19 (Kader Pen CO).

Hasil penelitian mendapatkan adanya hubungan antara pedagang yang memiliki keyakinan rentan tertular COVID-19 dengan kepatuhan pedagang dalam menjalani protokol kesehatan di pasar. Sejalan dengan penelitian Romanov di Italia, menyatakan persepsi kerentanan berpengaruh terhadap kepatuhan masyarakat untuk menekan penularan COVID-19 (Romanov, 2020) Teori HBM menjelaskan upaya untuk memprediksi perilaku tindakan kesehatan yang akan dilakukan diantaranya kerentanan dirasakan berlandaskan kemungkinan yang ada dalam memaparkan kesulitan Kesehatan (Atkinson et al., 1997). WHO mengatakan, semua kalangan masyarakat rentan tertular COVID-19 secara langsung maupun tidak langsung (WHO 2020). Pasar merupakan tempat yang rentan transmisi COVID-19 (Engkus et al., 2019). Pedagang yang merasa dirinya rawan terpapar COVID-19 sehingga akan berupaya mencari pencegahan dan mengikuti anjuran yang dihimbaukan. Untuk meningkatkan kesadaran dirinya dapat rentan tertular COVID-19 dibutuhkan penyebaran informasi melalui publik figure seperti ketua paguyuban pasar melalui group online.

Hasil penelitian mengungkapkan, keyakinan yang dirasakan pedagang bahwa COVID-19 merupakan penyakit yang serius berhubungan dengan kepatuhan pedagang dalam menjalani protokol kesehatan di pasar. Hal ini dikarenakan terdapat keluarga dekat maupun tetangga yang pernah tertular dan meninggal akibat COVID-19 sehingga ketakutan yang mendalam bahwa COVID19 merupakan penyakit yang serius dapat cepat menular dan mengakibatkan kematian. Penelitian ini sejalan dengan Tong di Hong Kong yang mengatakan keyakinan masyarakat akan keseriusan awal dalam menanggapi COVID-19 berhubungan dengan perilaku pencegahannya (Tong et al., 2020). Untuk meningkatkan persepsi keseriusan guna meningkatkan kepatuhan pedagang dilakukan peningkatan pengetahuan melalui media informasi online melalui grup paguyuban.

Rosenstock dalam teori HBM menjelaskan kemungkinan individu melakukan perilaku

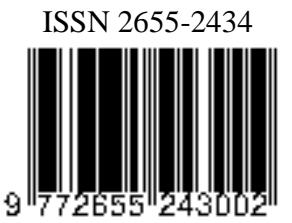


pencegahan dipengaruhi oleh rintangan yang dirasakan. Berdasarkan penelitian, keyakinan hambatan yang dirasakan pedagang menunjukan berhubungan dengan kepatuhan pedagang dalam menjalani protokol kesehatan (McKenzie et al., 2013) Hal ini dikarenakan rintangan yang ada menjadikan penghalang dalam mematuhi protokol kesehatan. Penghalang tersebut dapat dikarenakan kurangnya pengetahuan pedagang akan protokol kesehatan, kurangnya dukungan dari keluarga terdekat, kurangnya ketersediaan sarana protokol kesehatan dan pengawasan yang ada di pasar. Penelitian ini sesuai dengan Fadilah yang menyatakan keyakinan terdapatnya hambatan berhubungan dengan kepatuhan masyarakat dalam menjalankan protokol kesehatan dalam masa Adaptasi Kebiasaan Baru (AKB) untuk mencegah penyebaran COVID-19 (Fadilah et al., 2020). Begitu pula dengan penelitian Tong di Cina yang mengemukakan keyakinan hambatan berhubungan dengan kepatuhan pedagang melakukan protokol kesehatan untuk mencegah COVID-19 sesuai dengan anjuran WHO (Tong et al., 2020). Untuk mengatasi hambatan tersebut dibutuhkan pemenuhan fasilitas protokol kesehatan seperti sarana cuci tangan di setiap koridor toko, sedangkan pengawasan dapat dilakukan melalui Sispenling CO.

Terdapat hubungan yang signifikan antar pedagang yang mempunyai isyarat dalam bertindak dengan kepatuhan menjalani protokol Kesehatan. Hal ini dikarenakan pedagang merasa mendapatkan dukungan dari keluarga untuk mematuhi protokol kesehatan. Selain itu dukungan keluarga yang diberikan juga sebagai pengingat dalam menjalaninya. Penelitian ini diperkuat Teori HBM yang menyatakan kepercayaan memicu tindakan seseorang dalam berperilaku sehat (McKenzie et al., 2013) Penelitian Fadilah mengatakan, seseorang yang memiliki isyarat dalam bertindak akan lebih patuh menjalankan protokol kesehatan (Fadilah et al., 2020) Begitu pula penelitian Elgzar et.al yang dilakukan pada mahasiswi Universitas Najran, isyarat untuk bertindak memiliki hubungan yang signifikan dengan kepatuhan dalam mencegah COVID-19 (Elgzar et al., 2020). Dukungan yang dilakukan dapat berupa ajakan dan penyemangat melalui media informasi baik cetak maupun elektronik sehingga pedagang tidak hanya mendapat dukungan dari keluarga namun melalui lingkungan

(C) Poltekkes Kemenkes Jakarta I

Jl. Wijaya Kusuma No. 47-48 Cilandak Jakarta Selatan, Indonesia email: jurnalquality@poltekkesjakarta1.ac.id pasar.

Penelitian ini menunjukan, tidak adanya hubungan antara umur pedagang dengan kepatuhan pedagang menjalani protokol kesehatan di pasar. Hal ini dikarenakan antara umur 18-45 tahun dan 46-65 tahun berada di satu populasi dengan ketersediaan informasi yang sama sehingga dibutuhkan peningkatan informasi serta pengawasan di pasar baik melalui multimedia. Menurut Wacker mengemukakan, pada usia 20-40 tahun mendorong penyebaran dikarenakan kebanyakan tidak menyadari bahwa mereka telah terinfeksi (Wacker, 1990) WHO mengatakan, semua kalangan umur rentan tertular SARS-COV2. Sejalan dengan penelitian Lau, usia tidak mempengaruhi dalam mematuhi kebijakan karantina yang dilakukan pemerintah (WHO, 2020).

Menurut Satuan Tugas penanganan COVID-19, terkonfirmasi COVID-19 pada 21 Desember 2020 hampir sebanding antara laki-laki dan perempuan. Hasil penelitian ini menunjukan, tidak adanya hubungan antara jenis kelamin dengan kepatuhan pedagang menjalani protokol kesehatan di pasar. Hal ini dikarenakan pedagang di pasar tidak dibatasi menurut jenis kelamin, demikian pula dengan protokol kesehatan yang telah ditetapkan dan diberlakukan tidak mengindahkan jenis kelamin serta semua kalangan dapat mencegah penularan COVID-19 melalui protokol kesehatan. Penelitian ini sejalan dengan Mulasari, mobilitas yang tinggi seperti berkumpul dengan komunitasnya kemungkinan menurunkan daya tahan tubuh yang terjadi pada laki-laki dan perempuan (Mulasari, 2015).

Penelitian ini mendapatkan bahwa tidak adanya hubungan antara keyakinan pedagang akan manfaat dengan kepatuhan pedagang dalam menjalani protokol kesehatan. Penelitian Pan di Senzhen Cina sejalan yang menyatakan tidak adanya hubungan yang signifikan antara keyakinan akan manfaat yang dirasakan dengan kepatuhan individu dalam menjalankan jaga jarak untuk pencegahan COVID19 (Pan et al., 2020) Begitu pula penelitian Romanov di Italia menyatakan, tidak ada hubungan yang bermakna antara persepsi manfaat dengan kepatuhan masyarakat menjalankan pencegahan COVID-19 (Romanov, 2020) Hal ini kemungkinan dikarenakan masa inkubasi SARS-COV2 terjadi 1428 hari sehingga manfaat yang dirasakan secara

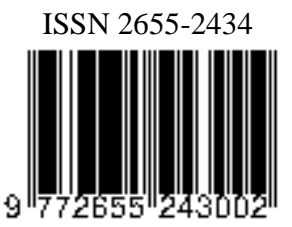


tidak langsung oleh pedagang dalam melakukan pencegahan COVID-19 (Olapegba P.O, 2020). Untuk mengatasi hal ini, diperlukan pencerahan kepada pedagang akan manfaat dalam mematuhi protokol kesehatan. Menurut penelitian ini, tidak adanya hubungan antara kemampuan diri dengan kepatuhan dalam menjalankan protokol kesehatan di pasar yang dikarenakan pedagang yang merasa mampu ataupun tidak mampu diharuskan menjalani protokol Penelitian Roma et.al memperkuat penelitian ini yang mnyatakan cara meningkatkan kepatuhan menggunakan alat pelindung diri pada saat pandemik dengan kemampuan diri kurang berpengaruh (Roma et al., 2019)

\section{Kesimpulan dan Saran}

Kepatuhan pedagang dalam menjalani protokol kesehatan di pasar masuk kedalam kategori kurang patuh. Faktor pengetahuan, persepsi kerentanan, persepsi keseriusan, persepsi hambatan dan kemampuan diri merupakan yang berhubungan dengan kepatuhan pedagang dalam menjalani protokol kesehatan.

Untuk Perusahaan Umum Daerah Pasar Tohaga Kabupaten Bogor dan Kecamatan Cibinong disarankan menyediakan masker 3 lapis cuci pakai serta saranan cuci tangan disetiap koridor pasar, memenuhi media informasi seperti speaker sentral, SMS LBA (Location Based Advertising), media cetak (baliho/spanduk). Selain itu Perumda pasar Tohaga Kecamatan Cibinong Bersama UPT Puskesmas setempat turut mendukung pembentukan pemberdayaan masyarakat guna meningkatkan pengetahuan seperti membentuk kader pencegahan COVID-19 (PenCO), sedangkan untuk pengawasan prokes dapat dibentuk sistem keamanan keliling pencegahan COVID-19 (Sispenling CO).

\section{Singkatan}

SARS-COV2: Severe Acute Respiratory Syndrome

Coronavirus 2

COVID-19: Coronavirus Disease 2019

HBM: Health Belief Model

Sispenling CO: Sistem Pencegahan Keliling COVID-19

Kader PenCO: Kader Pencegahan COVID-19

\section{Daftar Pustaka}

Atkinson, R., Atkinson, R., Smith, E., Bem, D., (C) Poltekkes Kemenkes Jakarta I

J1. Wijaya Kusuma No. 47-48 Cilandak Jakarta Selatan, Indonesia email: jurnalquality@poltekkesjakarta1.ac.id
Nolen-Hoeksema, S., Rathus, S., \& Nallan, G. (1997). Introductory psychology textbooks: Four encyclopedic tomes. Psyccritiques, 42(5), 445-446.

Bogor, S. C. K. (2020). Peraturan Bupati Bogor Nomor 16 TAHUN 2020 Tentang Pelaksanaan Pembatasan Sosial berskala Besar Dalam Penangan Corona Virus Disease 2019 (COVID-19) Di Kabupaten Bogor. https://jdih.bogorkab.go.id/detailpost/perbupnomor-16-tahun-2020

BPS Kabupaten Bogor. (2018). Kecamatan Cibinong Dalam Angka 2018. https://bogorkab.bps.go.id/publication/2018/0 9/26/33250acc48f449de02d6915b/kecamatancibinong-dalam-angka-2018.html

Chairunisa, C., Syamsul, A., \& Rosida Lena. (2019). Faktor-faktor yang berhubungan dengan perilaku kepatuhan minum obat anti diabetes pada penderita diabetes melitus tipe 2 di Puskesmas Cempaka Banjarmasin.

Homeostasis, 2(1), 43-54.

Elgzar, W. T., Al-Qahtani, A. M., Elfeki, N. K., \& Ibrahim, H. A. (2020). Covid-19 outbreak: Effect of an educational intervention based on health belief model on nursing students' awareness and health beliefs at najran university, kingdom of saudi arabia. African Journal of Reproductive Health, 24(2 Special Edition COVID-19), 78-86. https://doi.org/10.29063/ajrh2020/v24i2s. 12

Engkus, Suparman, N., Sakti, F. T., \& Anwar, H. S. (2019). Covid-19: Kebijakan Mitigasi Penyebaran Dan Dampak Sosial Ekonomi Di Indonesia. Journal of Chemical Information and Modeling, 53(9), 1689-1699. https://doi.org/10.1017/CBO9781107415324.0 04

Fadilah, M., Pariyana, Apriliyana, S., \& Syakurah, R. . (2020). EVALUASI KEPATUHAN MASYARAKAT DALAM MENJALANKAN ADAPTASI. 000(November), 18-19.

frame.grid.id. (2020). Ngeyel Tak Jaga Jarak, 36 Pedagang Pasar di Padang Positif Corona \& 1000 Orang yang Belanja Langsung Dicari. https://fame.grid.id/read/462133844/ngeyeltak-jaga-jarak-36-pedagang-pasar-di-padangpositif-corona-1000-orang-yang-belanjalangsung-dicari?page $=$ all

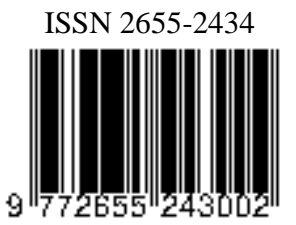


Kompas.com. (2020). Pasar Cileungsi Jadi Pusat

Penyebaran Covid-19, New Normal di

Kabupaten Bogor Terancam Bata Pasar

Cileungsi Jadi Pusat Penyebaran Covid-19,

New Normal di Kabupaten Bogor Terancam

Batal.

https://regional.kompas.com/read/2020/06/16/

12453321/pasar-cileungsi-jadi-pusat-

penyebaran-covid-19-new-normal-di-

kabupaten-bogor.

Lemeshow, S., Jr, D. W. H., Klar, J., \& Stephen K, L. (1997). Besar Sampel Dalam Penelitian Kesehatan (Gajah Mada University (ed.); 1st ed.).

McKenzie, J. F., Neiger, B. L., \& Thackeray, R. (2013). Planning, Implementing and Evaluating Health Promotion Programs: A Primer. In Journal of Physical Therapy Education (Vol. 19, Issue 2). https://doi.org/10.1097/00001416-20050700000017

Mulasari, F. D. (2015). Economics Development Analysis Journal. 4(2), 254-263.

Mulyati, L., Rachman, D., \& Herdiana, Y. (2016). Fakor Determinan yang Memengaruhi Budaya Keselamatan Pasien di RS Pemerintah Kabupaten Kuningan Determinant factors that are Influencing Patient Safety Culture in a Government-owned Hospitals in Kuningan Regency. Jurnal Keperawatan Padjadjaran, 4(2), 179-190.

Nismawati, N., \& Marhtyni, M. (2020). Faktor Yang Berhubungan Dengan Penerapan Protokol Kesehatan Pada Pelaku Usaha Mikro Selama masa Pandemi Covid -19. UNM Environmental Journals, 3(3), 116. https://doi.org/10.26858/uej.v3i3.16210

Notoatmodjo, S. (2014). Ilmu Perilaku (Ke-2). Rineka Cipta.

Olapegba P.O. (2020). A Preliminary Assessment of Novel Coronavirus (COVID-19) Knowledge and Perceptions in Nigeria. https://www.medrxiv.org/content/10.1101/202 $0.04 .11 .20061408 \mathrm{v} 2$

Pan, Y., Fang, Y., Xin, M., Dong, W., Zhou, L., \& Hou, Q. (2020). Self-Reported Compliance With Personal Preventive Measures Among Chinese Factory Workers at the Beginning of Work Resumption Following the COVID-19

(C) Poltekkes Kemenkes Jakarta I

J1. Wijaya Kusuma No. 47-48 Cilandak Jakarta Selatan, Indonesia email: jurnalquality@ poltekkesjakarta1.ac.id
Outbreak : Cross-Sectional Survey Study Corresponding Author : 22, 1-19. https://doi.org/10.2196/22457

Roma, P., Monaro, M., Muzi, L., Colasanti, M., Ricci, E., Biondi, S., Napoli, C., Ferracuti, S., \& Mazza, C. (2019). How to Improve Compliance with Protective Health Measures during the COVID-19 Outbreak: Testing a Moderated Mediation Model and Machine Learning Algorithms. 1(Desember 2019), 117.

Romanov, B. K. (2020). Coronavirus disease COVID-2019. Safety and Risk of

Pharmacotherapy. https://doi.org/10.30895/2312-7821-2020-8-13-8

Satgas COVID19. (2020a). Peraturan Bupati Bogor Nomor 16 Tahun 2020 Tentang Pelaksanaan Pembatasan Sosial Berskala Besar Dalam Penanganan Corona Virus Disease 2019 Di Kabupaten Bogor. In SELL Journal (Vol. 5, Issue 1).

Satgas COVID19. (2020b). Peraturan Bupati Bogor Nomor 40 Tahun 2020 Tentang Pembatasan Sosial Berskala Besar Pada Masa Transisi Menuju Masyarakat Sehat, Aman Dan Produktif.

Satgas COVID19 Kabupaten Bogor. (2020). Peraturan Bupati Bogor Nomor 60 Tahun 2020 Tentang Pelaksanaan Pembatasan Sosial Berskala Besar Pra Adaptasi Kebiasaan Baru Menuju Masyarakat Sehat, Aman Dan Produktif Di Kabupaten Bogor.

Shahnazi. (2020). Assessing Preventive Health Behaviors from COVID-19 Based on the Health Belief Model ( HBM) among People in Golestan Province : A Cross-Sectional Study in Northern Iran.

Siahaineinia, Edison, H., Bakara, \& Lince, T. (2020). Persepsi Masyarakat Tentang Penggunaan Masker Dan Cuci Tangan Selama Pandemi COVID-19. 9(1).

Tong, K. K., Chen, J. H., Yu, E. W. yat, \& Wu, A. M. S. (2020). Adherence to COVID-19 Precautionary Measures: Applying the Health Belief Model and Generalised Social Beliefs to a Probability Community Sample. Applied Psychology: Health and Well-Being, 1-19. https://doi.org/10.1111/aphw.12230

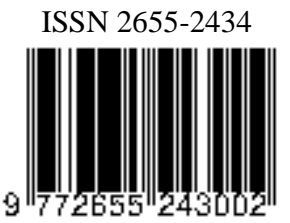


tribunnews.com. (2020). PSBB dan Physical

Distancing Enggak Ngaruh di Pasar Ciluar,

Masyarakat Tetap Berjubel, Berdesakan.

https://cirebon.tribunnews.com/2020/05/21/ps

bb-dan-physical-distancing-enggak-nagaruh-

di-pasar-ciluar-masyarakat-tetap-berjubelberdesakan

Wacker, R. R. (1990). The Health Belief Model and preventive health behavior : an analysis of alternative models of causal relationships.

Retrospective Theses and Dissertations, 9417, $1-173$.

Wade, C., Travis, C., \& Garry, M. (2016). Psikologi

(O. M. Dwiasri, C. G.P.H, \& A. Maulana

(eds.)). Penerbit Erlangga.

WHO. (2020). Coronavirus disease 2019 (COVID-

19) Situation Report - 52.

https://www.who.int/docs/default-

source/coronaviruse/situation-

reports/20200312-sitrep-52-covid-

19.pdf?sfvrsn=e2bfc9c0_4

Wiranti, Sriatmi, A., \& Kusumastuti, W. (2020).

Determinan kepatuhan masyarakat Kota

Depok terhadap kebijakan pembatasan sosial

berskala besar dalam pencegahan COVID-19.

Jurnal Kebijakan Kesehatan Indonesia,

09(03), 117-124.

https://journal.ugm.ac.id/jkki/article/view/584

84 